\title{
Effect on reclamation on mercury concentration in groundwater: a case study of Luboń Chemical Plant (Poznań, Poland)
}

\author{
Artur Kowalski $^{1} \cdot$ Anetta Zioła-Frankowska $^{2} \cdot$ Marcin Frankowski ${ }^{1}$
}

Received: 20 March 2018 / Accepted: 19 September 2018 / Published online: 26 September 2018

(c) The Author(s) 2018

\begin{abstract}
Luboń Chemical Plant (Poland), founded in 1914, is the place where many products such as superphosphate, hydrofluoric acid, sulfuric acid, aluminum fluoride, potassium fluoroborate, vanadium catalyst and other chemicals and post-production waste have been produced and stored. The main products manufactured by Luboń Chemical Plant are powdered superphosphate (obtained from apatite) and sulfuric acid (obtained from pyrite) The aim of the study was to determine the impact of the former post-crystallization leachate disposal site located in the area of Lubon Chemical Plant on groundwater contamination with mercury. Groundwater samples were collected from 12 piezometers in the area of the plant or in close vicinity to the plant, and from one piezometer located $2.5 \mathrm{~km}$ north of the study area, i.e., from Poznań-Dębina groundwater intake, in the years 2007-2014. Total mercury concentration in groundwater from Luboń was high in all samples, and ranged from 10.9 to $2818 \mathrm{ng} \mathrm{L}^{-1}$ (average $335 \pm 509 \mathrm{ng} \mathrm{L}^{-1}$, median $=158 \mathrm{ng} \mathrm{L}^{-1}$ ). The highest mercury concentration values were measured in piezometer no. 7, located in close proximity to the production facilities of the chemical plant, and they equaled $2604 \mathrm{ng} \mathrm{L}^{-1}$ in 2007 and $2818 \mathrm{ng} \mathrm{L}^{-1}$ in 2008 . The lowest concentration of mercury (10.9 $\mathrm{ng} \mathrm{L}^{-1}$ ) was determined in 2014, in a sample taken from piezometer no. 13 located at the water intake for the agglomeration of Poznań (Poznań-Dębina). Based on the obtained results, two sources of groundwater pollution were found: (1) Luboń Chemical Plant, and (2) former post-crystallization leachate disposal site. A decrease in mercury concentrations with increasing distance of piezometers from the pollution sources was reported. Moreover, a reduction in mercury concentration over the years has been observed, especially after completion of reclamation and remediation works in the area of Luboń Chemical Plant in 2008. Despite the negative impact of the plant on groundwater quality measured in the piezometer located at the water intake Poznań-Dębina, the drinking water quality guidelines $\left(1000 \mathrm{ng} \mathrm{L}^{-1}\right)$ was not exceeded.
\end{abstract}

Keywords Mercury $\cdot$ Groundwater $\cdot$ Chemical plant $\cdot$ Pollution $\cdot$ Reclamation

\section{Introduction}

Mercury constitutes a significant threat to the environment and human health due to its toxicity, ability to bioaccumulate and high mobility (Navarro 2008; Wang et al. 2012; Pérez-Sanz et al. 2012; Lodenius 2013; Gupta and Nirwan 2015; Kowalski and Frankowski 2015). Mercury is quite

Artur Kowalski

artur.kowalski@amu.edu.pl

1 Department of Water and Soil Analysis, Faculty of Chemistry, Adam Mickiewicz University in Poznań, Umultowska 89b, 61-614 Poznań, Poland

2 Department of Analytical Chemistry, Faculty of Chemistry, Adam Mickiewicz University in Poznań, Umultowska 89b, 61-614 Poznań, Poland common in the natural environment, it exists in ores and in the form of different minerals. As a result of natural processes such as rock weathering, small quantities of mercury are emitted to the atmosphere, surface waters and groundwater (Nriagu 1989; Kabata-Pendias 2001; Fay and Gustin 2007; González-Fernández et al. 2014). The natural content of mercury in groundwater is difficult to calculate. Barringer et al. (2013) estimated that the background value for the area of New Jersey is $<10 \mathrm{ng} \mathrm{L}^{-1}$. Szymczycha et al. (2013) measured mercury concentrations in wells located by the Gulf of Gdańsk, in the southern part of the Baltic Sea, and obtained values of $0.51-1.15 \mathrm{ng} \mathrm{L}^{-1}$. Lindqvist et al. (1991) determined mercury levels of $16.5 \mathrm{ng} \mathrm{L}^{-1}$ (median of $2.0 \mathrm{ng} \mathrm{L}^{-1}$ ) in groundwater in Sweden, while Krabbenhoft and Babiarz (1992) obtained values of $2-4 \mathrm{ng} \mathrm{L}^{-1}$ for Wisconsin (USA). Average concentrations of mercury in 
groundwater of background areas of the USA, i.e., South Florida, determined by Harvey et al. (2002), were from 0.7 to $1.4 \mathrm{ng} \mathrm{L}^{-1}$, while average mercury content of groundwater in Poznań (Poland), measured by Kowalski et al. (2007), was $1.3 \pm 0.7 \mathrm{ng} \mathrm{L}^{-1}$ (range $0.8-4.1 \mathrm{ng} \mathrm{L}^{-1}$ ).

Nevertheless, most of the mercury in the environment comes from anthropogenic sources (Pacyna and Pacyna 2002; Zahir et al. 2005; Wong et al. 2006; Pacyna et al. 2010). The main anthropogenic source of mercury in the environment, mostly in the atmosphere, is the burning of fossil fuels and municipal solid waste, as well as emissions from hospital incinerators (Zahir et al. 2005; Kowalski et al. 2012; Barringer et al. 2013). Moreover, mercury is released to the environment from mining waste (extraction and processing of mercury and gold), from the production of metals, cement and caustic soda, during technological processes in chloralkali industry, from other industries such as production of paper, pharmaceuticals and chemicals (chemical fertilizers, mercury electrolysis, synthesis of plastics), electrical engineering (production of UV and fluorescent lamps, measuring devices), armaments, petrochemical industry, and from laboratory waste, sewage sludge, ashes and deposits from combustion, disposal sites, dental amalgams and cremation. Such mercury-containing products as batteries, thermometers, fluorescent lamps, different instruments and electronic equipment, paints, pesticides and fertilizers can also contribute to the emission of mercury (Kabata-Pendias 2001; Mukherjee et al. 2004; Li et al. 2009). Mercury that is emitted into the atmosphere can be transported over thousands of kilometers and accumulate in soils, rivers, lakes, and seas (Bełdowski and Pempkowiak 2003; Zahir et al. 2005; Li et al. 2009; Wang et al. 2014; Chételat et al. 2015; Kowalski and Frankowski 2016). Anthropogenic mercury pollution is considered a global problem which may have consequences for human health, both immediate and longterm (Wang et al. 2012, 2014; De Simone et al. 2014; Jang et al. 2014; González-Fernández et al. 2014; Chételat et al. 2015). Mercury can be leached from soil into surface water or groundwater and pose a threat to human health, especially when these waters are used for consumption (Barringer et al. 2010, 2013; González-Fernández et al. 2014). The transformation of mercury and its transport from contaminated soil into surface water and groundwater depend on geological, hydrological and climatic processes, as well as on land use and soil properties and composition (Kabata-Pendias 2001; Kowalski et al. 2007; Bollen et al. 2008; Reis et al. 2010; Bhagure and Mirgane 2011; González-Fernández et al. 2014; Kowalski and Frankowski 2016). However, not all mercury that contaminates soil can migrate into groundwater, because soil has a buffering capacity and thus can adsorb contaminants (Kowalski et al. 2007; Barringer et al. 2013; González-Fernández et al. 2014). In recent years, a number of studies have focused on the problem of soil and groundwater contamination with mercury as a result of rapid industrialization and urbanization (Kortatsi 2007; Bollen et al. 2008; Barringer et al. 2010, 2013; Bhagure and Mirgane 2011; Wu and Cao 2010; González-Fernández et al. 2014). Industrial and agricultural activity of point and area sources of mercury can lead to contamination of groundwater (Bollen et al. 2008; Bhagure and Mirgane 2011; Barringer et al. 2013). The studies on mercury concentration in the vicinity of urban complexes, metal mines or industrial sites showed that these areas contain high levels of mercury (Bollen et al. 2008; Boszke et al. 2008; Bhagure and Mirgane 2011). Industrial disposal sites and municipal waste landfills generate a lot of leachate, and when they are inadequately protected it can result in the migration of pollutants into surface water and groundwater (Bhagure and Mirgane 2011). Concentrations of mercury released from anthropogenic sources to the environment are much higher than the background values (Pacyna et al. 2010). Mercury in contaminated soils and groundwater can cause a major threat to ecosystems due to its bioaccumulation. Therefore, the study of groundwater composition is important in the assessment of environmental pollution with mercury and potential threat to human health, especially in industrial areas.

Over many years, continuous production of different chemicals in Luboń Chemical Plant has adversely affected the natural environment. In the present study, based on samples from 2007 to 2014, we focused on the impact of Lubon Chemical Plant, including former post-crystallization leachate disposal site, on the contamination of groundwater with mercury. We estimated the influence of the plant on mercury concentration in the reference well located in the area of the "Poznań-Dębina" water intake for the city of Poznań, and compared the obtained results with the maximum concentration level of mercury that is allowed in drinking water in Poland and with the value recommended by WHO (World Health Organization). Furthermore, the objective of the study was to assess the impact of reclamation and remediation works carried out by Luboń Chemical Plant on the improvement of groundwater quality in the study area.

\section{Study area}

Luboń Chemical Plant is a place where different kinds of chemical products, raw materials and post-production waste have been produced and stored since 1914 . The post-crystallization leachate generated in the production process has been stored in the form of semi-fluid pulp at the disposal site located in the area of the plant. In the 1980s of last century, such chemicals as superphosphate, hydrofluoric acid, sulphuric acid, aluminum fluoride, potassium fluoroborate and vanadium catalyst were also produced there. Currently, the plant produces among other things mainly fertilizers, wood and fabric preservatives, and hydrofluoric acid. In addition 
to the reclamation works focused on the post-crystallization leachate disposal site, in 2005-2008 the chemical plant introduced new technologies to eliminate the emission of contaminants in particulate matter, gases and waste into the atmosphere, soil and groundwater. A number of safeguards to minimize the impact of chemical production on the environment were implemented. The chemical plant is located in the south-eastern part of the town of Lubon, $2.5 \mathrm{~km}$ south of the "Dębina" artificial recharge well field (Poznań, Poland). The plant takes up an area of about 59 ha. To the north of the chemical plant, there are industrial grounds and afforested areas spreading across the meanders of the Warta River. The location of sampling points is presented in Fig. 1a.

To the south of the plant, there is an aggregate mine, and in a distance of about $0.7 \mathrm{~km}$ runs the border of the Wielkopolski National Park. The eastern border of the plant is determined by the Warta River, while the western border is composed of old river beds of the Warta River, separated from the main stream of the river but still filled with water. In a distance of about $200 \mathrm{~m}$ to the southwest of the chemical plant there used to be a post-crystallization leachate disposal site. The post-production disposal facility was a dammedup underground tank with a built-up superstructure, which did not contain any additional safety devices to reduce the migration of pollutants to the water-bearing layer. It took up the area of about 2 ha, its removal began in 2005 and was finished in 2008.

\section{Hydrogeological setting}

In the study area, there is one unconfined aquifer, which is dependent on fluctuations in the water level of the river. Groundwater is drained by the Warta River, however, in the periods of high water level the river may have an infiltration character (Fig. 1b). The Warta Valley water-bearing reservoir in the area of Chemical Plant in Lubon (Poland) is filled with Quaternary sediments with a thickness of 4-20 m. Holocene sediments, with the predominance of fine sands, occur up to a depth of 4-10 $\mathrm{m}$ in p.p.t. The lower part of the reservoir is Pleistocene sediments, consisting of medium and coarse-grained sands, lined with gravels. While the aquatic sediments constitute clays from tertiary sediments. Additionally, some cemented sands (anthropogenic sandstone) occur in the ground of the post-liquor effluent and in the area of chemical plant. The sources of groundwater pollution in the area of the chemical plant are: industrial buildings, raw materials and post-production waste stored on the ground, acid tanks, loading platforms and reclaimed postcrystallization leachate disposal site. The characterization of hydrogeological cross-section across the Warta River valley in the region of the chemical plant in Lubon is presented by Frankowski et al. (2010).

\section{Materials and methods}

\section{Sampling}

Groundwater samples for mercury analysis were collected from 13 wells and observation holes in the area of the chemical plant (Luboń, Poland) and from the area of the former post-crystallization leachate disposal site, using a deep well pump. A total of 91 samples were collected in the years 2007-2014. The map showing the chemical plant in Luboń is presented in Fig. 1a. Based on the marked direction of groundwater flow, the sampling points were distributed as follows:

- Sampling points no. 1-3, located in the southern sector according to the groundwater flow lines, from old river bed and former post-crystallization leachate disposal site in Luboń towards the Warta River bed, near the village of Czapury.

- Sampling points no. 4-12, located in the northern sector following the groundwater flow lines from the area of the chemical plant to the Warta River meander near Marlewo.

Sampling point (piezometer) no. 13 was located $2.5 \mathrm{~km}$ to the north of the chemical plant, towards the "PoznanDębina" water intake for the city of Poznań, (Poland). Water samples for the analysis were collected after purging water in a hole at least three times and after stabilization of basic physical parameters in the purged water. Water samples were collected using ultraclean sampling techniques, into borosilicate bottles of $0.10 \mathrm{~L}$ volume. The samples were acidified to $\mathrm{pH}=2$, with concentrated nitric acid, and transported to the laboratory at $4{ }^{\circ} \mathrm{C}$, in a mobile refrigerator.

\section{Analytical techniques}

The following reagents of analytical grade: hydrochloric acid and nitric acid (Sigma-Aldrich, USA), potassium bromide and potassium bromate (Merck, Darmstadt, Germany), intended for the determination of mercury, were used in the analysis. Tin (II) chloride (Merck, Darmstadt, Germany) applied in the preparation of the reducing solution was of low mercury content. Working standard solutions were prepared on each day of analysis by diluting the stock standard solution of $\mathrm{Hg}\left(\mathrm{NO}_{3}\right)_{2}\left(1000 \pm 4 \mathrm{mg} \mathrm{L}^{-1}\right.$, Sigma-Aldrich, USA). Prior to each use, all glass containers for mineralization were soaked in $10 \%(\mathrm{v} / \mathrm{v})$ nitric acid for $24 \mathrm{~h}$ and washed three times with demineralized water (Hydrolab, Poland). To remove traces of mercury, 


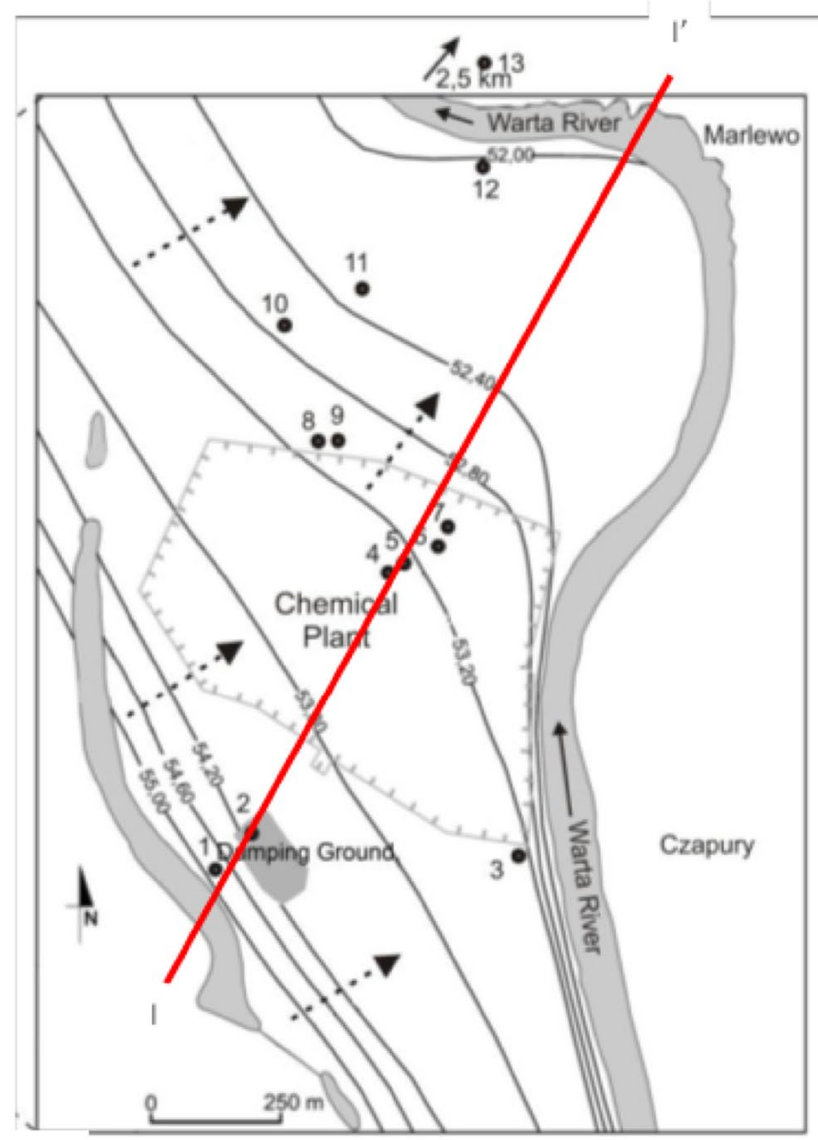

(a)

\section{$I-I^{\prime}$ : Hydrogeological cross section}

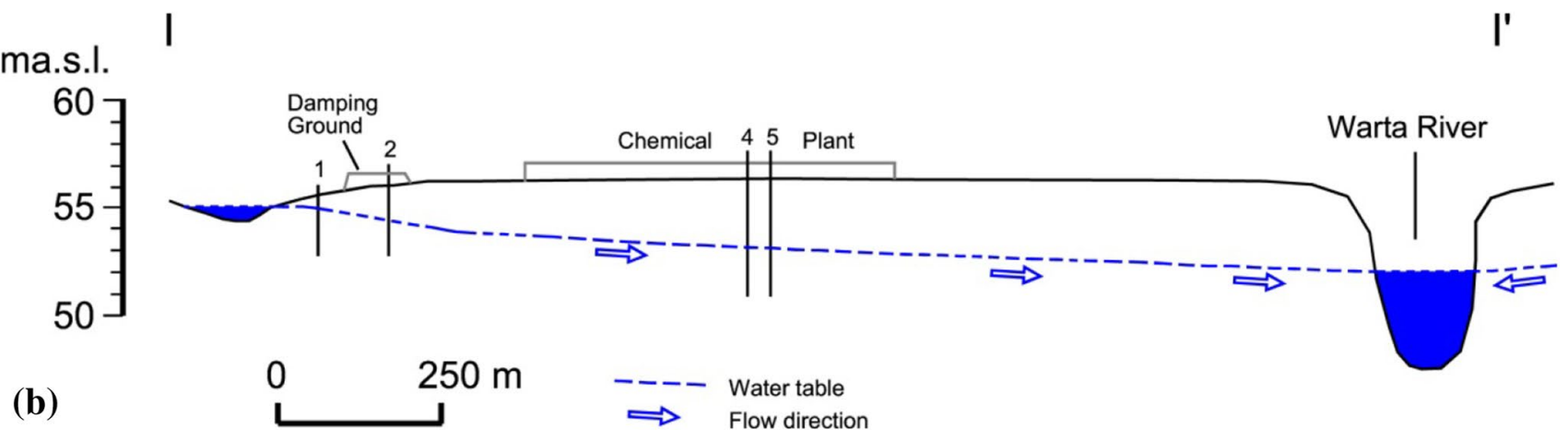

Fig. 1 a Hydrogeological map with the sampling points (piezometers no. 1-13), b hydrogeological cross-section

demineralized water was purged with argon for $6 \mathrm{~h}$, and the reducing solution $\left(2 \% \mathrm{~m} / \mathrm{v}\right.$ of $\mathrm{SnCl}_{2}$ in $\left.10 \% \mathrm{v} / \mathrm{v} \mathrm{HCl}\right)$ was purged with argon for $1 \mathrm{~h}$ prior to analysis. All samples and standards were stored in borosilicate glass bottles. The concentration of mercury in groundwater was determined by cold vapor generation atomic fluorescence spectrometry CV-AFS (Millennium Merlin Analyzer 10.025,
PS Analytical, England), based on established US EPA Method 1631. To determine the precision and accuracy of the analytical procedure, a five-point calibration curve was performed. The percentage recovery of $\mathrm{Hg}$ from duplicate spike standard solutions measured at the beginning and every ten samples ranged from 98 to $103 \%$. Additionally, to verify and control the applied method, a certified 
reference material was used (ORMS-3, National Research Council Canada). The method recovery was $98 \pm 5 \%$ and the detection limit (calculated as 3SD of blank samples) was $0.2 \mathrm{ng} \mathrm{L}^{-1}$.

\section{Results and discussion}

Mercury concentrations in groundwater samples collected from piezometers no. 1-12, located in the area of the Chemical Plant in Luboń, and from piezometer no. 13, located in the area of water intake "Poznań-Dębina" in Poznań, are shown in Table 1.

Concentrations of total mercury in groundwater from Luboń reached average values of $335 \pm 509 \mathrm{ng} \mathrm{L}^{-1}$, with a median of $158 \mathrm{ng} \mathrm{L}^{-1}$. The highest mercury concentrations were determined in piezometer 7 (Table 1), located in close proximity to production facilities of the chemical plant. The lowest concentration of mercury was determined in 2014, in a sample taken from piezometer 13 located at the water intake "Poznań-Dębina". The evolution of mercury concentration between 2007 and 2014 is shown in Fig. 2. The results of the Wilcoxon test $(\alpha=0.05)$ showed lower, statistically different average mercury concentrations for piezometers no. $6(p=0.04252), 5(p=0.04298)$ and 2 $(p=0.01796)$.

Based on the obtained results, presented in Table 2, two main sources of groundwater mercury contamination were indicated: chemical plant (piezometers 4-7) and former post-crystallization leachate disposal site (piezometer 2). The same sources of contamination were pointed out by Siepak (2005) in the case of arsenic, selenium and antimony, and by Frankowski et al. (2010) and Frankowski (2012) for fluorine and aluminum compounds. In the study area, the migration of contaminants is connected with their leaching from ground surface caused by precipitation and their infiltration into deeper zones of the aquifer (see Fig. 1b). Below the water table, the contaminants are diluted in groundwater.

When analyzing the results of mercury in piezometers 1-3 (Table 2), we observed a strong influence of the postcrystallization leachate disposal site on mercury content in the examined water samples. The average concentration of mercury in piezometer no. 1 for the years 2007-2014 was $61.8 \pm 30.0 \mathrm{ng} \mathrm{L}^{-1}$, which was over 9 times lower compared to the values obtained for piezometer 2 . And in 2008, the concentration of mercury in piezometer $1\left(88.5 \mathrm{ng} \mathrm{L}^{-1}\right)$ was over 14 times lower than the concentration in piezometer 2 . The groundwater in the southern sector flows from the old river bed and former post-crystallization leachate disposal site towards the meander of the Warta river (north of the Czapury village), and then it is diluted, as suggested by the results of mercury for piezometer no. 3. The average mercury concentration for this piezometer was $144.9 \pm 77.9 \mathrm{ng}$ $\mathrm{L}^{-1}$, and the maximum value of $241.7 \mathrm{ng} \mathrm{L}^{-1}$ was determined in 2007. The results obtained for piezometer no. 3 were much lower than those for piezometer no. 2. The Wilcoxon test $(p=0.01796)$ showed that the concentration in piezometer 3 was statistically different and higher than the average concentration of mercury in piezometer 1 . We can conclude that the spatial distribution of mercury for the southern sector was associated with leaching from the postcrystallization disposal site caused by precipitation and by water contained in a semi-liquid pulp.

Based on the obtained results (Table 2), it was noted that average mercury concentration increased with the direction of groundwater flow in that area both for the northern
Table 1 Mercury concentrations (ng $\mathrm{L}^{-1}$ ) in groundwater samples, in the years 20072014

\begin{tabular}{|c|c|c|c|c|c|c|c|}
\hline \multirow[t]{2}{*}{ Piezometer } & \multicolumn{7}{|c|}{ Sampling date } \\
\hline & $\begin{array}{l}09.2007 \\
\left(\mathrm{ng} \mathrm{L}^{-1}\right)\end{array}$ & 09.2008 & 09.2009 & 09.2010 & 09.2011 & 09.2012 & 09.2014 \\
\hline 1 & 109.3 & 88.5 & 69.5 & 58.7 & 43.7 & 41.5 & 21.5 \\
\hline 2 & 1440 & 1315 & 491.5 & 213.8 & 208.9 & 214.2 & 41.4 \\
\hline 3 & 241.7 & 209.1 & 216.4 & 122.6 & 96.2 & 95.9 & 32.8 \\
\hline 4 & 1071 & 496.6 & 183.4 & 105.3 & 75.1 & 44.5 & 16.3 \\
\hline 5 & 1559 & 1041 & 1131 & 210.3 & 182.3 & 58.0 & 35.6 \\
\hline 6 & 1481 & 1020 & 923.8 & 562.4 & 383.4 & 211.3 & 71.8 \\
\hline 7 & 2604 & 2818 & 868.2 & 946.1 & 593.9 & 298.4 & 84.4 \\
\hline 8 & 300.8 & 277.0 & 201.7 & 143.6 & 53.9 & 36.6 & 25.7 \\
\hline 9 & 422.5 & 435.6 & 375.0 & 280.8 & 266.4 & 158.3 & 27.8 \\
\hline 10 & 243.1 & 244.2 & 189.4 & 112.5 & 46.5 & 42.3 & 31.6 \\
\hline 11 & 289.1 & 283.0 & 194.6 & 127.7 & 47.5 & 44.2 & 33.3 \\
\hline 12 & 149.7 & 166.9 & 140.9 & 169.5 & 57.7 & 47.4 & 28.6 \\
\hline 13 & 79.9 & 81.8 & 61.8 & 67.3 & 43.6 & 20.4 & 10.9 \\
\hline
\end{tabular}


Fig. 2 Mercury concentration (ng L ${ }^{-1}$ ) in piezometers

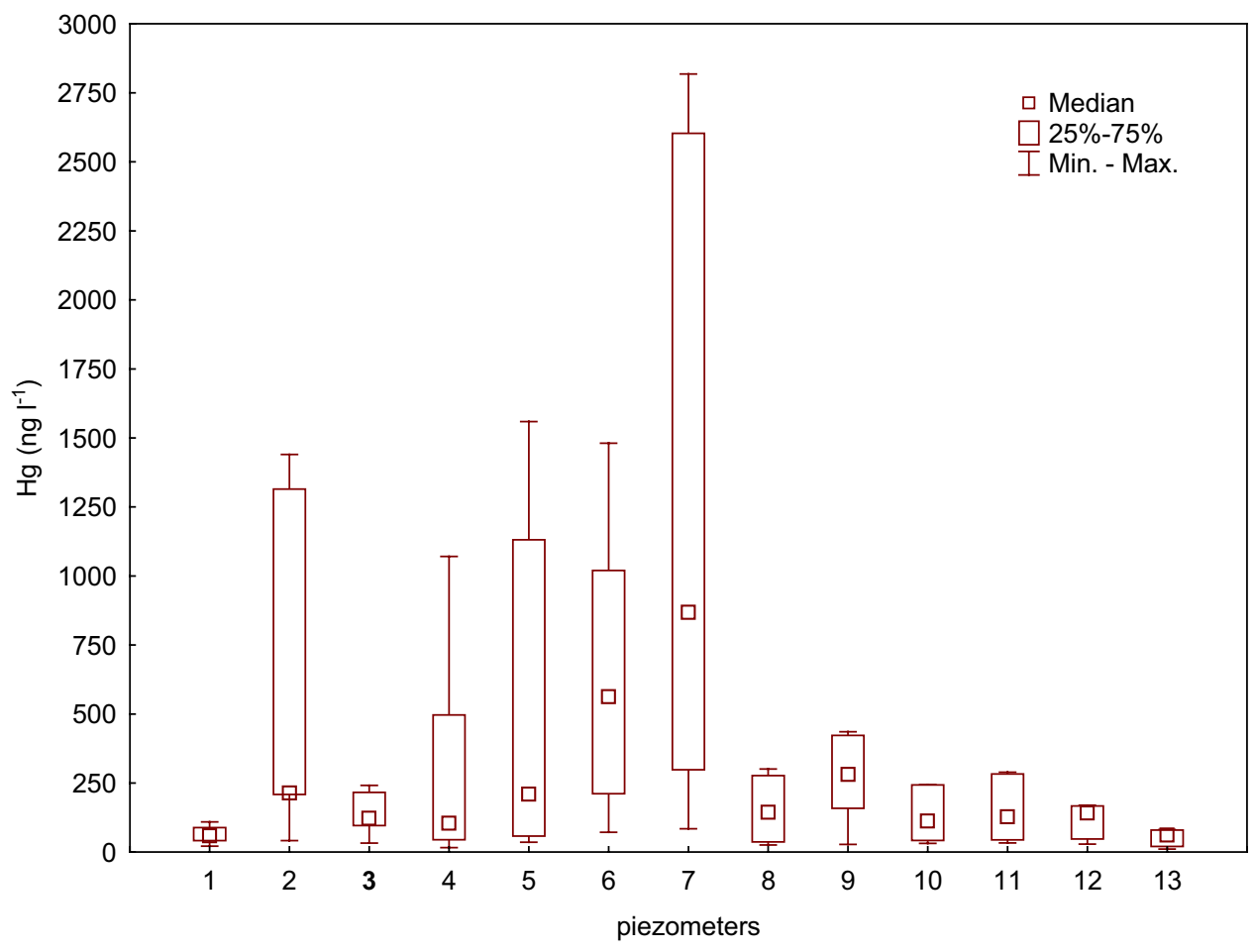

Table 2 Statistical summary of mercury concentrations determined in 13 piezometers $\left(\mathrm{ng} \mathrm{L}^{-1}\right)$

\begin{tabular}{lcccc}
\hline Piezometer & Average \pm S.D. & Median & Min. & Max. \\
\hline 1 & $61.8 \pm 30.0$ & 58.7 & 21.5 & 109.3 \\
2 & $560.7 \pm 574.5$ & 214.2 & 41.4 & 1440 \\
3 & $144.9 \pm 77.9$ & 122.6 & 32.8 & 241.7 \\
4 & $284.6 \pm 382.7$ & 105.3 & 16.3 & 1071 \\
5 & $602.5 \pm 623.9$ & 210.3 & 35.6 & 1559 \\
6 & $664.8 \pm 501.0$ & 562.4 & 71.8 & 1481 \\
7 & $1173 \pm 1094$ & 868.2 & 84.4 & 2818 \\
8 & $148.5 \pm 114.8$ & 143.6 & 25.7 & 300.8 \\
9 & $280.9 \pm 148.4$ & 280.8 & 27.8 & 435.6 \\
10 & $129.9 \pm 94.9$ & 112.5 & 31.6 & 244.2 \\
11 & $145.6 \pm 111.6$ & 127.7 & 33.3 & 289.1 \\
12 & $108.7 \pm 61.3$ & 140.9 & 28.6 & 169.5 \\
13 & $52.2 \pm 28.1$ & 61.8 & 10.9 & 81.8 \\
\hline
\end{tabular}

and southern zones. The main direction of groundwater flow from the chemical plant area is towards the meander of the Warta river near the village of Marlewo (Siepak 2005; Frankowski 2012). Lower mercury concentrations in piezometers 8-12, which were distant from the chemical plant, indicated the dilution of contaminants in groundwater flowing from the old river bed. Similar dependence, i.e., decrease in groundwater mercury concentration with the distance from industrial facilities, was observed by Bollen et al. (2008) for the area of former wood impregnation factory. In our study, average mercury concentrations in water collected from piezometers $8-9$, located in the vicinity of the chemical plant, were lower than those for piezometers 4-7, while the concentrations determined for piezometers 10-12, which were the furthest from the chemical plant, were the lowest. The sources of groundwater contamination in the northern sector were: industrial buildings, raw materials and postproduction waste stored on the ground, acid tanks and loading platforms. The data presented in Fig. 3 indicate the variability in mercury concentration for the period 2007-2014.

Average mercury concentrations in groundwater were considerably higher for the period before completion of the reclamation works in the area of the post-crystallization leachate disposal site, i.e., until 2008 (Table 3).

In 2007, the average concentration of mercury was the highest. The measurable effects of these changes (decreased concentration of mercury in groundwater) have been observed since 2008 . The lowest values of mercury were determined in water samples collected in 2014. The average mercury concentration for 2014 was over 20 times lower than that determined in 2007. Based on the results of mercury in groundwater samples from the years 2007-2014, the Shapiro-Wilk test $(\alpha=0.05)$ was performed. It was found that the distribution of mercury values obtained for the years of the measurement period is not normal (Table 3). The Wilcoxon matched-pairs test, in which we compared the values from the consecutive years, i.e., 2007-2008, 2008-2009, 2009-2010, 2010-2011, 2011-2012 and 2012-2014, showed that only the results from 2007 to 
Fig. 3 Variability in mercury concentration for the study period of 2007-2014

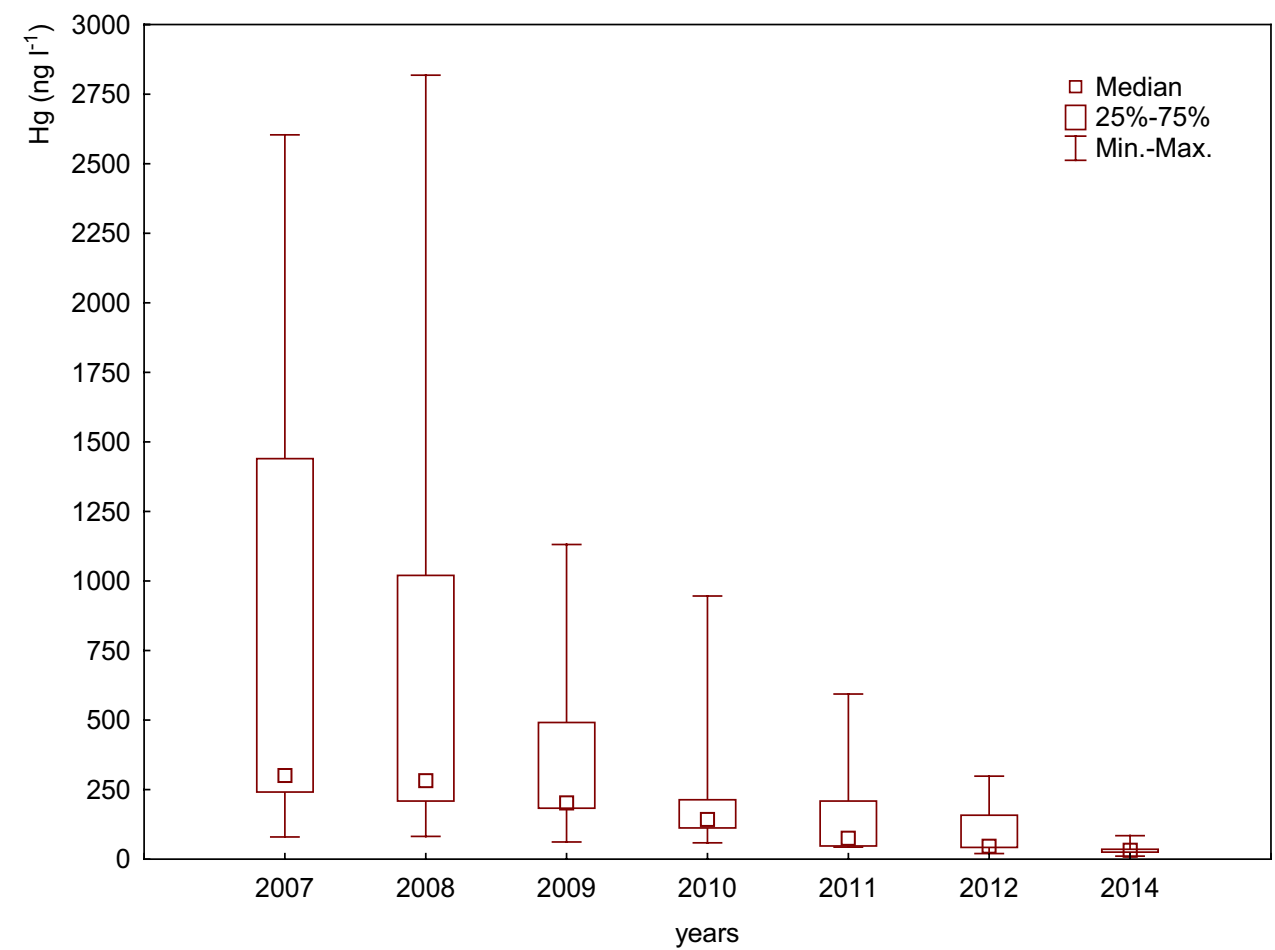

Table 3 Statistical summary of mercury concentrations determined in 91 groundwater samples, in the years 2007-2014 $\left(\mathrm{ng} \mathrm{L}^{-1}\right)$

\begin{tabular}{cccccl}
\hline Year & Average \pm SD & Median & Min. & Max. & Shapiro-Wilk test \\
\hline 2007 & $768.5 \pm 788.2$ & 300.8 & 79.9 & 2604 & 0.0091 \\
2008 & $652.1 \pm 764.2$ & 283.0 & 81.8 & 2818 & 0.0011 \\
2009 & $388.2 \pm 357.4$ & 201.7 & 61.8 & 1131 & 0.0066 \\
2010 & $240.0 \pm 248.9$ & 143.6 & 58.7 & 946.1 & 0.0003 \\
2011 & $161.5 \pm 167.8$ & 75.1 & 43.6 & 593.9 & 0.0020 \\
2012 & $101.0 \pm 89.5$ & 47.4 & 20.4 & 298.4 & 0.0049 \\
2014 & $35.5 \pm 20.7$ & 31.6 & 10.9 & 84.4 & 0.0139 \\
\hline
\end{tabular}

2008 were not statistically different $(p=0.1005)$. In the other years, the obtained values were statistically different $(2008-2009, p=0.01310 ; 2009-2010, p=0.01559$; $2010-2011, p=0.00147 ; 2011-2012, p=0.00465$; 2012-2,014, $p=0.005$ ). The obtained values (Table 1) were compared with mercury concentrations determined by Kowalski et al. (2007) in groundwater samples (mean $1.3 \pm 0.7 \mathrm{ng} \mathrm{L}^{-1}$; range $0.8-4.1 \mathrm{ng} \mathrm{L}^{-1}$ ) collected from the emergency wells for the city of Poznań, which is bordered by Luboń to the north. Although Poznań is considered to be an industrial city, concentrations of mercury in groundwater were not high. We conclude that mercury concentrations in the piezometers from Luboń, especially in the years 2007-2008, indicate industrial contamination coming from the chemical plant. In the urban area of New Jersey mercury concentrations ranged from 50 to $250 \mathrm{ng} \mathrm{L}^{-1}$ (Barringer et al. 2013). In the industrial area (cement plants, steel plants and coal power plants) of north-western Spain, the maximum value of mercury concentration in groundwater was 10,200 ng L ${ }^{-1}$ (González-Fernández et al. 2014). In southern Germany, in the area of former wood impregnation factory, where $\mathrm{HgCl}_{2}$ had been used as an impregnation component until 1965, the values of mercury in groundwater were from 500 to $229,000 \mathrm{ng} \mathrm{L}^{-1}$, depending on the distance of piezometers from the factory (Bollen et al. 2008). In the industrial region of Maharashtra (India), Bhagure and Mirgane (2011) determined mercury in groundwater in the range of 1290-12,000 $\mathrm{n} \mathrm{L}^{-1}$, while in the region of Ankobra Basin (Ghana), where mercury is used in gold mining, Kortatsi (2007) reported that groundwater concentrations of this element ranged from $<50$ to $36,800 \mathrm{ng} \mathrm{L}^{-1}$. Based on the mercury values measured in the present study, we found a negative effect of the chemical plant in Lubon on the content of this metal in groundwater obtained from piezometer 13 (2.5 km from the plant). Piezometer 13 is located in a short distance from the Warta River, in the southern part of the area of Poznań-Dębina water intake, which provides drinking water for the city of Poznan. It was observed that high levels of mercury in piezometers 2 and 4-7, in the years 2007-2008, are connected with elevated concentrations in water taken from piezometer 13 .

After the reclamation and remediation works had been completed by the chemical plant, a decrease in mercury levels in the following years (2009-2014) was also observed for piezometer 13. The highest concentration of $\mathrm{Hg}$ was 
determined in $2008\left(81.8 \mathrm{ng} \mathrm{L}^{-1}\right)$, and it decreased more than 7 times to reach $10.8 \mathrm{ng}$ of $\mathrm{L}^{-1}$ in 2014 . In the case of piezometer 13, it was also found that water from the Warta causes dilution of pollutants flowing through the riverbed from the chemical plant. The Wilcoxon test showed that the average concentration of mercury in piezometer 13 $\left(52.2 \pm 28.1 \mathrm{ng} \mathrm{L}^{-1}\right)$ was lower and statistically different than the concentrations in piezometers $12(p=0.018)$ and $3(p=0.0177)$, located in close vicinity to the Warta and on the same side of the river as the Chemical Plant in Luboń. Concentrations of mercury in piezometer 13 did not exceed the allowable value of $1000 \mathrm{ng} \mathrm{L}^{-1}$, required by Polish law (Regulation of the Minister of Health 2015) and the directives of the European Union (EU 1998) concerning the quality of drinking water. Higher mercury values for drinking water are allowed by the Environmental Protection Agency (EPA 2012) - $2000 \mathrm{ng} \mathrm{L}^{-1}$ for children $<10 \mathrm{~kg}$, and for a standard $70-\mathrm{kg}$ adult person. Mercury limit set by WHO (2011) is $6000 \mathrm{ng} \mathrm{L}^{-1}$. The Joint FAO/WHO Expert Committee on Food Additives (JECFA) proposed the value of $4 \mu \mathrm{g} \mathrm{kg}^{-1}$ bw per week (JECFA 2010) as a provisionally tolerable weekly intake (PTWI) for inorganic mercury. The EPA has also established a reference dose for chronic oral exposure (RfD) to inorganic mercury as $0.3 \mu \mathrm{g}$ per kg body weight per day (EPA 2007). Assuming that the highest concentration of mercury determined in piezometer 13 (water intake Poznań-Dębina) was $81.8 \mathrm{ng} \mathrm{L}^{-1}$, and that a standard 60-kg person drinks 2 liters of water per day, the person would consume about $1.15 \mu \mathrm{g}$ of $\mathrm{Hg}$ in a week, which is less than $0.5 \%$ of the tolerable weekly intake $(4 \mu \mathrm{g} \times 60 \mathrm{~kg}$ per week). In contrast, the highest obtained mercury concentration in piezometer $7\left(2818 \mathrm{ng} \mathrm{L}^{-1}\right)$ would give the consumption of slightly more than $16 \%$ of the tolerable weekly intake for a $60-\mathrm{kg}$ person. However, it should be noted that mercury gets to a human body not only with drinking water but also with food, dietary supplements and medicines, and with the air (Zahir et al. 2005; Wu and Cao 2010; Kowalski and Frankowski 2015). Assuming the level of mercury in the ambient air as $10 \mathrm{~kg} \mathrm{~m}^{-3}$, the average daily absorption of inorganic mercury via inhalation is about $0.2 \mu \mathrm{g}$ (WHO 2005). The average daily intake of mercury from food is in the range of 2-20 $\mu \mathrm{g}$. In the areas of significant environmental pollution with mercury, the above values can be much higher (WHO 2005).

\section{Conclusions}

Based on the results obtained in the present study, it was found that the Chemical Plant in Lubon, founded in 1914, and the post-crystallization leachate disposal site were the significant sources of mercury contamination to groundwater. Mercury concentrations in the samples collected in the period from 2007 to 2014 showed that the sources of $\mathrm{Hg}$ contamination to groundwater were: industrial buildings, raw materials and post-production waste stored on the ground, acid tanks and loading platforms. In the area of the disposal site, where the deposition of contaminants was finished in 1991, large amount of waste and the lack of any protection, e.g., soil-sealing layers, caused that contaminants entered the ground, and through the aeration zone, they got to the aquifer. The reclamation and remediation works, conducted in 2008 by the chemical plant, limited the impact of chemical production on the environment. The matchedpairs Wilcoxon test carried out for groundwater concentrations of $\mathrm{Hg}$ in consecutive years, showed a decreasing trend that started in 2008, both for piezometers in the area of the chemical plant in Luboń and for piezometers which are distant from the plant. Based on this test, we also found that water collected from piezometer 13 (Poznań-Dębina water intake) was diluted by water from the Warta river. Despite the negative impact of the chemical plant on the quality of groundwater, the allowable mercury level $\left(1000 \mathrm{ng} \mathrm{L}^{-1}\right)$ was not exceeded for drinking water from piezometers 8 to 13 . However, the production of chemicals in the plant was the most intensive until mid- $80 \mathrm{~s}$ of last century, and there is no information on mercury concentrations in groundwater for that period because the measurements were not conducted. We can only suppose that the emission of contaminants into soil, groundwater and the air was larger when the production of chemicals was greater. Currently, the mercury content in groundwater poses no threat to human health because mercury levels in groundwater are much lower than the values proposed by WHO as the provisional tolerable weekly intake of mercury ( $4 \mathrm{~g} \mathrm{~kg}^{-1}$ bw per week) (JECFA 2010). However, it should be remembered that mercury which gets to soil and water can be absorbed by living organisms and accumulated or biomagnified through the food chain. It is, therefore, very important to monitor each component of the environment, especially in the area of a chemical plant which can be a potential source of mercury, e.g., in the case of malfunction.

Open Access This article is distributed under the terms of the Creative Commons Attribution 4.0 International License (http://creativeco mmons.org/licenses/by/4.0/), which permits unrestricted use, distribution, and reproduction in any medium, provided you give appropriate credit to the original author(s) and the source, provide a link to the Creative Commons license, and indicate if changes were made.

\section{References}

Barringer JL, Riskin ML, Szabo Z, Reilly PA, Rosman R, Bonin JL, Fischer JM, Heckathorn HA (2010) Mercury and methylmercury dynamics in a Coastal Plain Watershed, New Jersey, USA. Water Air Soil Pollut 212:251-273 
Barringer JL, Szabo Z, Reilly PA, Riskin ML (2013) Variable contributions of mercury from groundwater to a first-order urban coastal Plain Stream in New Jersey, USA. Water Air Soil Pollut 224:1475

Bełdowski J, Pempkowiak J (2003) Horizontal and vertical variabilities of mercury concentration and speciation in sediments of the Gdansk Basin, Southern Baltic See. Chemosphere 52(3):645-654

Bhagure GR, Mirgane SR (2011) Heavy metal concentrations in groundwaters and soils of Thane Region of Maharashtra, India. Environ Monit Assess 173:643-652

Bollen A, Wenke A, Biester H (2008) Mercury speciation analyses in $\mathrm{HgCl} 2$-contaminated soils and groundwater-implications for risk assessment and remediation strategies. Water Res 42:91-100

Boszke L, Kowalski A, Astel A, Baranowski A, Gworek B, Siepak J (2008) Mercury mobility and bioavailability in soil from contaminatedarea. Environ Geol 55:1075-1087

Chételat J, Braune B, Stow J, Tomlinson S (2015) Special issue on merkury in Canada's North: summary and recommendations for future research. Sci Total Environ 509-510:260-262

Council Directive (1998) 98/83/EC of 3 November on the quality of water intended for human consumption. Off $\mathrm{J}$ Eur Communities 330:32-54

De Simone F, Gencarelli CN, Hedgecock IM, Pirrone N (2014) Global atmospheric cycle of mercury: a model study on the impact of oxidation mechanisms. Environ Sci Pollut Res 21:4110-4123

EPA (2007) Chemical summary, inorganic mercury. U.S. Environmental Protection Agency, Washington

EPA (2012) Edition of the drinking water standards and health advisories. U.S. Environmental Protection Agency, Washington

Fay L, Gustin M (2007) Assessing the influence of different atmospheric and soil mercury concentrations on foliar mercury concentrations in a controlled environment. Water Air Soil Pollut $181: 373-384$

Frankowski M (2012) Simultaneous determination of aluminium, aluminium fluoride complexes and iron in groundwater samples by new HPLC-UVVIS method. Microchem J 101:80-86

Frankowski M, Zioła-Frankowska A, Siepak J (2010) Speciation of aluminium fluoride complexes and $\mathrm{Al} 3+$ in soils from the vicinity of an aluminium smelter plant by hyphenated high performance ion chromatography flame atomic absorption spectrometry technique. Microchem J 95:366-372

González-Fernández B, Menéndez-Casares E, Meléndez-Asensio M, Fernández-Menéndez S, Ramos-Muñiz F, Cruz-Hernández P, González-Quirós A (2014) Sources of mercury in groundwater and soils of west Gijón (Asturias, NW Spain). Sci Total Environ 481:217-231

Gupta S, Nirwan J (2015) Evaluation of mercury biotransformation by heavy metal-tolerant Alcaligenes strain isolated from industrial sludge. Int J Environ Sci Technol 12:995-1002

Harvey JW, Krupa SL, Gefvert C, Mooney RM, Choi J, King SA, Giddings JB (2002) Ground-water component of the mercury budget at ENR. Interactions between surface water and ground water and effects on mercury transport in the north-central everglades. U.S. Department of the Interior, U.S. Geological Survey, Center for Coastal Geology

Jang H-N, Kim J-H, Jung S-J, Back S-K, Sung J-H, Kim S-H, Seo Y-C, Keel S-I, Lu X (2014) Mercury emission characteristics from coal combustion by supplying oxygen and carbon dioxide with limestone injection. Fuel Process Technol 125:217-222

JECFA (2010) Food and Agriculture Organization of the United Nations World Health Organization Joint FAO/WHO Expert Committee On Food Additives. Seventy second meeting Rome

Kabata-Pendias A (2001) Trace elements in soil and plants. CRC Press, Washington, D. C

Kortatsi BK (2007) Hydrochemical framework of groundwater in the Ankobra Basin. Ghana Aquat Geochem 13:41-74
Kowalski A, Frankowski M (2015) Levels and potential health risks of mercury in prescription, non-prescription medicines and dietary supplements in Poland. Regul Toxicol Pharmacol 73:396-400

Kowalski A, Frankowski M (2016) Seasonal variability of mercury concentration in soils, buds and leaves of Acer platanoides and Tilia platyphyllos in central Poland. Environ Sci Pollut Res 23:9614-9624

Kowalski A, Siepak M, Boszke L (2007) Mercury contamination of surface and ground waters of Poznań, Poland. Pol J Environ Stud 16(1):67-74

Kowalski A, Frankowski M, Zioła-Frankowska A, Mocek-Płóciniak A, Siepak J (2012) Variability of mercury concentrations in soil and leaves of Acer plantanoides and Tilia platyphyllos in Poznań city, Poland. Soil Sed Contamin 21:1022-1031

Krabbenhoft DP, Babiarz CL (1992) The role of groundwater transport in aquatic mercury cycling. Water Resour Res 28:3119-3128

Li P, Feng XB, Qiu GL, Shang LH, Li ZG (2009) Mercury pollution in Asia: a review of the contaminated sites. J Hazard Mater 168:591-601

Lindqvist O, Johansson K, Aastrup M, Andersson A, Bringmark L, Hovsenius G, Håkanson L, Iverfeldt Å, Meili M, Timm B (1991) Mercury in the Swedish environment-recent research on causes, consequences, and corrective methods. Water Air Soil Pollut $55: 1-262$

Lodenius M (2013) Use of plants for biomonitoring of air borne mercury in contaminated areas. Environ Res 125:113-123

Mukherjee AB, Zevenhoven R, Brodersen J, Hylander LD, Bhattacharya $P$ (2004) Mercury in waste in the European Union: sources, disposal methods and risks. Resour Conserv Recycl 42:155-182

Navarro A (2008) Review of characteristics of mercury speciation and mobility from areas of mercury mining in semi-arid environments. Rev Environ Sci Biotechnol 7:287-306

Nriagu JO (1989) A global assessment of the natural sources of atmospheric trace metals. Nature 338:47-49

Pacyna EG, Pacyna JM (2002) Global emission of mercury from anthropogenic sources in 1995. Water Air Soil Pollut 137:149-165

Pacyna EG, Pacyna JM, Sundseth K, Munthe J, Kindbom K, Wilson S, Steenhuisen F, Maxson P (2010) Global emission of mercury to the atmosphere from anthropogenic sources in 2005 and projections to 2020. Atmos Environ 44:2487-2499

Pérez-Sanz A, Millán R, Sierra MJ, Alarcón R, García P, Gil-Díaz M, Vazquez S, Lobo MC (2012) Mercury uptake by Silene vulgaris grown on contaminated spiked soils. J Environ Manage 95:233-237

Regulation of the Minister of Health (2015) In the quality of water intended for human consumption. Dz.U. (Journal of Laws ) from 2015, item 1989, 1-32

Reis AT, Rodrigues SM, Davidson CM, Pereira E, Duarte AC (2010) Extractability and mobility of mercury from agricultural soils surrounding industrial and mining contaminated areas. Chemosphere $81: 1369-1377$

Siepak M (2005) Arsenic, antimony and selenium occurred in ground water of the Warta river valley between Poznań and Śrem. Geologos Monographiae 1. Bogucki Wydawnictwo Naukowe

Szymczycha B, Miotk M, Pempkowiak J (2013) Submarine groundwater discharge as a source of Merkury in the Bay of Puck, the Southern Baltic Sea. Water Air Soil Pollut 224:1542

Wang J, Feng X, Anderson CWN, Xing Y, Shang L (2012) Remediation of mercury contaminated sites-a review. Environ Res 125:113-123

Wang F, Wang S, Zhang L, Yang H, Wu Q, Hao J (2014) Mercury enrichment and its effects on atmospheric emissions in cement plants of China. Atm Environ 92:421-428

WHO (2005) Mercury in drinking-water. World Health Organization, Geneva 
WHO (2011) Guidelines for drinking-water quality, 4th edn. World Health Organization, Geneva

Wong CSC, Duzgoren-Aydin NS, Aydin A, Wong MH (2006) Sources and trends of environmental mercury emissions in Asia. Sci Total Environ 368:649-662

Wu G-H, Cao S-S (2010) Mercury and cadmium contamination of irrigation water, sediment, soil and shallow groundwater in a wastewater-irrigated field in Tianjin, China. Bull Environ Contam Toxicol 84:336-341

Zahir F, Rizwi SJ, Haq SK, Khan RH (2005) Low dose mercury toxicity and human health. Environ Toxicol Pharmacology 20:351-360 